Historia Slavorum Occidentis

2020, $\mathrm{nr} 2(25)$

ISSN 2084-1213

DOI: $10.15804 /$ hso200203

Marcin Danielewski (Poznań)

ORCID: 0000-0003-3897-2617

\title{
Wpływy ruskie we władztwie Piastów X-XI w. w kontekście badań interdyscyplinarnych nad wschodnią Wielkopolską i Kujawami*
}

Słowa kluczowe: Wielkopolska, Kujawy, Ruś, Kruszwica, cmentarzyska

Keywords: Wielkopolska [Great Poland], Kujawy, Kruszwica, cemeteries

\begin{abstract}
This paper discusses the problem of Polish-Ruthenian contacts at an early stage of the Piast realm (from the rule of Mieszko I to the end of Mieszko II's rule), focusing on the significance of written sources. It also looks at place names, possibly related to the Ruthenian population, and archaeological sources.
\end{abstract}

\section{Wstęp}

Problematyka kontaktów Rusi z władztwem Piastów wzbudza od dawna zainteresowanie zarówno historyków, jak i archeologów. W polskiej nauce przez cały XX w. zajmowano się tematyką kontaktów polsko-ruskich i obecnością wpływów ruskich we

* Praca naukowa finansowana w ramach programu Ministra Nauki i Szkolnictwa Wyższego pod nazwą „Narodowy Program Rozwoju Humanistyki” w latach 2014-2020 - projekt nr 0040/ NPRH3/H11/82/2014. W prezentowanym artykule skupiamy swoją uwagę na okresie zamykającym się między panowaniem Mieszka I a końcem rządów Mieszka II. Wyjątkowo będziemy wychodzić poza ten horyzont czasowy, sięgając np. do okresu rządów Kazimierza Odnowiciela, aby pełniej ukazać kontakty polsko-ruskie. Natomiast, chcemy również podkreślić, że artykuł ma charakter przyczynkarski i nie może stanowić pełnego omówienia problemu, ten bowiem wymaga przedstawienia w osobnej książkowej publikacji. 
władztwie Piastów, ze szczególnym uwzględnieniem okresu X-XI w. ${ }^{1}$ Zagadnienia

1 Wśród historyków problematykę tę podejmowali m.in.: B. Włodarski, Wołyń pod rządami Rurykowiczów i Bolesława Jerzego Trojdenowicza, Rocznik Wołyński 3 (1934), s. 105-146 (zwłaszcza s. 105-114); T. Grudziński, Bolesław Szczodry. Zarys dziejów panowania, cz. 1. Toruń 1953, zwłaszcza s. 97-111; H. Łowmiański, Problematyka historyczna Grodów Czerwieńskich $w$ związku z planem zespołowych badań polsko-radzieckich, Kwart. Hist. 60 (1953), nr 1, s. 58-85; A. Poppe, Gród Wołyń. Z zagadnień osadnictwa wczesnośredniowiecznego na pograniczu polsko-ruskim, Studia Wczesnośredniowieczne 4 (1958), s. 227-296; B. Włodarski, Problem jaćwiński w stosunkach polsko-ruskich, Zap. Hist. 24 (1958-1959), z. 2-3, s. 7-35; F. Persowski, Studia nad pograniczem polsko-ruskim w X-XI wieku, Wrocław 1962; J. Bieniak, Źródło ruskie do sprawy Miecława, Studia Źródłoznawcze 8 (1963), s. 96-111; T. Grudziński, Bolesław Śmiaty-Szczodry i biskup Stanisław. Dzieje konfliktu, Warszawa 1982, passim; J. Powierski, Ruś w opiniach najważniejszych polskich kronikarzy, [w:] Polacy o Ukraińcach, Ukraińscy o Polakach. Materiaty z sesji naukowej, red. T. Stegner, Gdańsk 1993, s. 10-69; F. Sielicki, Polsko-ruskie stosunki kulturalne do końca XV wieku, Wrocław 1997, s. 13-29; A. Poppe, Spuścizna po Wtodzimierzu Wielkim. Walka o tron kijowski 1015-1019, Kwart. Hist. 102 (1995), nr 3-4, s. 5, 6-7, 11-15, 17-20; J. Kurtyka, Południowy odcinek granicy polsko-ruskiej we wczesnym średniowieczu (przed 1340 r.) w świetle źródeł historycznych, [w: ] Poczatki sąsiedztwa. Pogranicze etniczne polsko-rusko-słowackie w średniowieczu. Materiaty z konferencji - Rzeszów 9-11 V 1995, red. M. Parczewski, S. Czopek, Rzeszów 1996, s. 183-201; J. Strzelczyk, Bolesław Chrobry, Poznań 1999, s. 160-191; J. Bieniak, Państwo Miecława. Studium analityczne, wyd. 2, Warszawa 2010 (wyd. 1 z 1964 r.), s. 142-192; S. Kętrzyński, Kazimierz Odnowiciel (1034-1058), wstęp i oprac. M. Biniaś-Szkopek, Kraków 2010 (w oparciu o pierwodruk z 1961 r.), s. 61-62, 72-75, 78-80, 92, 95. Również archeolodzy chętnie podejmowali problem kontaktów polsko-ruskich: K. Jażdżewski, Cmentarzysko wczesnośredniowieczne w Lutomiersku pod Łodzia w świetle badan z r. 1949, Materiały Wczesnośredniowieczne 1 (1951), s. 121-122; Z. Wartołowska, Gród Czerwieński Sutiejsk na pograniczu polsko-ruskim, Światowit 22 (1958), s. 7-119; K. Jażdżewski, Ogólne wiadomości o Czermnie - Czerwieniu, Archeologia Polski 4 (1959), z. 1, s. 67-86; A. Zbierski, Wczesnośredniowieczne materiały archeologiczne z Czermna nad Huczwa (zabytki ruchome z wyjątkiem ceramiki), Archeologia Polski 4 (1959), z. 1, s. 105-147; T. Kiersnowska, O pochodzeniu rodu Awdańców, [w: ] Społeczeństwo Polski średniowiecznej. Zbiór studiów, t. 5, red. S. M. Kuczyński, Warszawa 1992, s. 57-72; M. Kara, Sity zbrojne Mieszka I. Z badań nad składem etnicznym, organizacja i dyslokacją drużyny pierwszych Piastów, Kronika Wielkopolska 62 (1993), nr 3, s. 40-42, 45; E. i A. Kokowscy, Trzy znaleziska wczesnośredniowieczne z Gródka nad Bugiem, woj. Zamość, Archeologia Polski 37 (1993), s. 209-213; ci sami, Miniaturowe relikwiarze-enkolpiony z Gródka nad Bugiem, Archeologia Polski Środkowo-Wschodniej 2 (1997), s. 287-288. Każdorazowo prezentujemy tylko wybraną literaturę przedmiotu, ponieważ problematyka kontaktów polsko-ruskich i wpływów ruskich we władztwie Piastów była wielokrotnie podejmowana na gruncie polskiej historiografii. Jednocześnie informujemy, że zasadniczo ograniczamy się do przedstawienia polskiej literatury przedmiotu, na uboczu raczej pozostawiając angielską, białoruską, rosyjską i ukraińską historiografię. Naukowcy z tych krajów zwykle bowiem omawiali kontakty polsko-ruskie w X-XI w., ale znacznie rzadziej podejmowali się tematyki wpływów ruskich we wczesnym władztwie Piastów. 
te zresztą w ostatnich dwudziestu latach również cieszyły się sporym zainteresowaniem środowiska naukowego ${ }^{2}$. Jeśli mamy na uwadze wczesny okres funkcjonowania

2 Wystarczy wspomnieć o licznych publikacjach podejmujących tę problematykę archeologów, zob. M. Wołoszyn, Bizantyjskie i ruskie zabytki o charakterze sakralnym z Polski - wybrane przykłady, [w:] Człowiek, sacrum, środowisko. Miejsca kultu we wczesnym średniowieczu, red. S. Moździoch, Wrocław 2000, s. 243-253; W. Panasiewicz, M. Wołoszyn, Staroruskie miniaturowe toporki z Gródka, pow. Hrubieszów, Archeologia Polski 47 (2002), z. 1-2, s. 245-272; K. Skalski, Mazowieckie groby w obudowach kamiennych $z$ rejonu Płocka. Przyczynek do historii politycznej drugiej potowy XI wieku, [w:] Inter Orientem et Occidentem. Studia z dziejów Europy Środkowowschodniej ofiarowane Profesorowi Janowi Tyszkiewiczowi w czterdziestolecie pracy naukowej, red. T. Wasilewski, Warszawa 2002, s. 51-64; R. Piotrowski, Uwagi na temat chronologii i interpretacji wczesnośredniowiecznych cmentarzysk mazowieckich, Archeologia Polski 48 (2003), z. 1-2, s. 182-191; M. Wołoszyn, Zabytki pochodzenia wschodniego we wczesnośredniowiecznej Polsce - wędrówka ludzi, rzeczy, czy idei?, [w:] Wędrówki rzeczy i idei w średniowieczu, red S. Moździoch, Wroclaw 2004, s. 241-253; M.P. Kruk, A. SulikowskaGąska, M. Wołoszyn, Sacralia Ruthenica. Early Ruthenian and Related Metal and Stone Items in the National Museum in Cracow and the National Museum in Warsaw, Warszawa 2006; M. Wołoszyn, Ze studiów nad obecnością ruska i skandynawska na ziemiach polskich $w X-$ -XII wieku, [w:] Świat Stowian wczesnego średniowiecza, red. M. Dworaczyk, A.B. Kowalska, S. Moździoch M. Rębkowski, Szczecin-Wrocław 2006, s. 595-606; tenże, Między Gnieznem, Krakowem a Kijowem. Archeologia o wczesnośredniowiecznych relacjach polsko-ruskich i formowaniu się polsko-ruskiego pogranicza, [w:] U źródeł Europy Środkowo-Wschodniej: pogranicze polsko-ukraińskie w perspektywie badań archeologicznych, red. M. Dębiec, M. Wołoszyn, Rzeszów 2007, s. 177-204; M. Florek, Topografia plemienna międzyrzecza Wieprza i Bugu na przełomie I i II tysiąclecia i zagadnienie "Grodów Czerwieńskich” w świetle źródet pisanych $i$ archeologicznych, [w:] Pogranicze polsko-ruskie we wczesnym średniowieczu na Lubelszczyźnie, red. E. Banasiewicz-Szykuła, Lublin 2009, s. 23-34; J. Kuśnierz, Znaleziska wczesnośredniowiecznych militariów w międzyrzeczu Wisty i Bugu jako materialne ślady konfliktów zbrojnych na pograniczu polsko-ruskim, [w:] Pogranicze polsko-ruskie we wczesnym średniowieczu na Lubelszczyźnie, red. E. Banasiewicz-Szykuła, Lublin 2009, s. 139-166; M. Wołoszyn, Obecność ruska i skandynawska w Polsce od X do XII w. - wybrane problemy, [w:] Wędrówka $i$ etnogeneza w starożytności i $w$ średniowieczu, red. M. Salamon, J. Strzelczyk, Kraków 2010, s. 299-320; T. Kurasiński, K. Skóra, Elementy „ruskie” w wyposażeniu pochówków z wczesnośredniowiecznego cmentarzyska (X-XII w.) w Lubieniu, pow. piotrkowski, [w:] „In silvis, campis... et urbe" średniowieczny obrzadek pogrzebowy na pograniczu polsko-ruskim, red. S. Cygan, M. Glinianowicz, P.N. Kotowicz, Rzeszów - Sanok 2011, s. 447-460; Czerwień - gród między Wschodem a Zachodem. Katalog wystawy, red. J. Bagińska, M. Piotrowski, M. Wołoszyn, Tomaszów Lubelski-Leipzig-Lublin-Rzeszów 2012; R. Grygiel, Cmentarzysko wareskich drużynników w Lutomiersku, [w:] Początki Łęczycy, t. 2 (Archeologia o początkach Łęczycy), red. R. Grygiel, T. Jurek, Łódź 2014, s. 733, 743-752; J. Kalaga, Co pozostało z wykopalisk na grodzisku w Sąsiadce, woj. lubelskie. Problemy badawcze po pięćdziesięciu czterech latach od ich zakończenia, [w:] Funkcje grodów w państwa wczesnośredniowiecznej Europy Środkowej. Społeczeństwo, gospodarka, ideologia, red. K. Chrzan, K. Czapla, S. Moździoch, Wrocław-Gło- 
domeny Piastów X-XI w. to wypada stwierdzić, że wiedza na temat tych kontaktów, wynikająca ze źródeł pisanych, jest dość ograniczona. Jest to skutek przede wszystkim skąpej podstawy źródłowej. W tym przypadku szczególnie na pierwszy plan wybijają się dwa teksty źródłowe: Kronika polska Anonima tzw. Galla oraz Повесть временных ^ет, gdzie znajduje się znacząca liczba informacji o kontaktach polsko-ruskich w X-XI w. ${ }^{3}$ Uzupełnieniem tych dwóch źródeł jest Kronika Thietmara, która również dostarcza wiadomości na temat relacji Piastów z Rurykowiczami

gów 2014, s. 335-351; P. Urbańczyk, Bolestaw Chrobry - lew ryczacy, Torun 2017, s. 234-240, 271-291; M. Wołoszyn, Cudzym bogom się nie kłaniaj? Interdyscyplinarność w badaniach Grodów Czerwieńskich, [w:] Stary materiat - nowe spojrzenie. Funeralia Lednickie. Spotkanie 20, red. W. Dzieduszycki, J. Wrzesiński, Poznań 2018, s. 47-52, 60-61. Wśród historyków intersującą problematyką zajmowali się w ciągu ostatnich kilkunastu lat m.in.: J. Tęgowski, Kontakty rodzinne dynastów polskich i ruskich w średniowieczu, [w:] Między sobą. Szkice historyczne polsko-ukraińskie, red. T. Chynczewska-Hennel, N. Jakowenko, Lublin 2000, s. 7-32 (zwłaszcza s. 7-12); A. Poppe, Gertruda-Olisawa, regina Russorum. Materiaty do życiorysu, [w:] Scriptura custos memoriae. Prace historyczne, red. D. Zydorek, Poznań 2001, s. 575-591; A. Grygorowicz, Gdzie Kazimierz Odnowiciel mógt poznać Marię-Dobroniegę, [w:] Polonia minor medii aevi. Studia ofiarowane Panu Profesorowi Andrzejowi Żakiemu w osiemdziesiąta rocznice urodzin, red. Z. Woźniak, J. Gancarski, Kraków-Krosno 2003, s. 525-528; П.П. Томочко, Русь и Полша в первой половине XI в., [w:] Ruś Kijowska i Polska w średniowieczu (X-XIII w.). Materiały konferencji Instytutu Historii PAN Warszawa 6-7 X 1998, red. S. Bylina, Warszawa 2003, s. 43-54; E. Madejczyk, Związki rodzinne Piastów i Rurykowiczów do końca XIII wieku, Przegląd Humanistyczny 48 (2004), nr 1, s. 95-103 (zwłaszcza s. 95-97, 100); $\Lambda$. Войтович, Княжа доба: портрети елити, Біла Церква 2006, passim; A.S. Fenczak, Wczesnośredniowieczny Przemyśl w świetle źródeł historycznych, [w:] Przemyśl wczesnośredniowieczny, red. E. Sosnowska, Warszawa 2010, s. 39-58; J. Chachaj, Lublin - miasto Rychezy? Lubelskie szkice historyczne XI-XIV wieku, Lublin 2014, s. 109-111; K. Kollinger, Polityka wschodnia Bolestawa Chrobrego (992-1025), Wrocław 2014; W. Brojer, Polska-Ruś w XI-XII w. Granica misyjności, [w:] Granica wschodnia cywilizacji zachodniej w średniowieczu, red. Z. Dalewski, Warszawa 2014, s. 297-373; D. Dąbrowski, Piasten und Rjurikiden vom 11. bis zur Mitte des 13. Jahrhunderts, [w:] Fernhändler, Dynasten, Kleriker. Die piastische Herrschaft in kontinentalen Beziehungsgeflechten vom 10. bis zum frühen 13. Jahrhundert, red. D. Adamczyk, N. Kersken, Wiesbaden 2015, s. 155-189; N. Delestowicz, Bolestaw II Szczodry. Tragiczne losy wielkiego wojownika 1040/1042-2/3 IV 1081 albo 1082, Kraków 2016, s. 113-118, 119-136, 179-188, 250-265, 318-334. Prezentujemy przede wszystkim polską literaturę przedmiotu, ponieważ ze względu na omawiane zagadnienia ona będzie nas głównie interesować.

3 Galli Anonymi Cronica et gesta ducum sive principum Polonorum, wyd. i wstęp K. Maleczyński, MPH n.s., t. II, Kraków 1952. Tekst tłumaczony Anonim tzw. Gall, Kronika polska, przekł. R. Grodecki, wstęp i oprac. M. Plezia, Wrocław 1982, ks. I, rozdz. 19, s. 41; Повесть временных ^ет, подготовка текста А.С. Аихачев, перевод А.С. Аихачев, Б.А. Романов, Москва 1950. 
w czasach panowania Mieszka I, Bolesława Chrobrego i Mieszka II oraz jego braci, a w mniejszym stopniu robią to również inne źródła niemieckie ${ }^{5}$. Wszelkie młodsze źródła polskie i ruskie należy raczej traktować jako materiał dodatkowy, w którym zwykle informacje na temat kontaktów polsko-ruskich z X-XI w. są powtarzane ze starszych kronik ${ }^{6}$. Spieszymy jednak podkreślić, że nie będziemy wszystkich zapisów źródłowych dotyczących relacji polsko-ruskich, a zawartych w kluczowych dla nas źródłach, szczegółowo prezentować, skupimy uwagę tylko na wybranych wiadomościach, które wskazują na przepływ ludności z Rusi do władztwa Piastów lub odwrotnie oraz na zmiennej przynależności danych terytoriów. Jest to tyle uzasadnione, że właśnie przepływ ludności z władztwa Rurykowiczów do domeny Piastów i odwrotnie (nawet jeśli miał on charakter przymusowy), powodował zwykle wymianę idei, obyczajów i przedmiotów.

\section{Źródła pisane}

Pierwsze informacje o kontaktach Rusi z władztwem Piastów odnoszą się do panowania Włodzimierza Wielkiego. Dane te dotyczą wydarzeń z 981 r., kiedy to Włodzimierz Wielki wyprawił się na „Lachów”: „В $\Lambda$ Ђто 6489. ИАе Володимеръ к мяхомъ и зая грады их, Перемышиь, Червенъ и ины, иже суть и до сего Ане подъ Русью”. Zapis ten w naukach historycznych wzbudzał poważne kontrowersje, które zasadniczo dotyczyły daty tego wydarzenia, pojęcia „Grody Czerwieńskie”, które utrwaliło się w historiografii, zwłaszcza polskiej, a także przynależności tego terytorium/ grodów $^{8}$. Kwestia ta nie została do tej pory jednoznacznie rozstrzygnięta, trudno

4 Kronika Thietmara, tłum., wstęp, koment. M.Z. Jedlicki, Poznań 1953.

5 Annales Hildesheimenses, wyd. G. Waitz, MGH SRG, t. VIII, Hannoverae 1878; Gesta Chuonradi II imperatoris, wstep J. Sochacki, tłum. E. Milkamanowicz, Kraków 2005.

6 W przypadku Polski będą to m.in. Magistri Vincentii dicti Kadłubek Chronica Polonorum, wyd. M. Plezia, MPH s.n., t. XI, Kraków 1994. Tekst tłumaczony: Mistrz Wincenty, Kronika polska, przekł. i komentarz B. Kürbis, Wrocław 1996; Chronica Poloniae Maioris, wyd. B. Kürbis, MPH s.n., t. VIII, Warszawa 1970. Tekst tłumaczony Kronika wielkopolska, przekł. K. Abgarowicz, wstęp i oprac. B. Kürbis, Warszawa 1965. W przypadku źródeł ruskich z reguły pierwszym członem wszelkich późniejszych latopisów była Повесть временных ^ет lub też wyciągi z niej, zob. Latopis Kijowski 1159-1198, przełożył i oprac. E. Goranin, Wrocław 1994, s. 11.

7 Повесть временных лет, s. 58.

8 Nie będziemy prezentować pełnej literatury przedmiotu do zagadnień związanych z tzw. „Grodami Czerwieńskimi”, a jedynie wskażemy najważniejsze opracowania, w których podsumowano tę problematykę. Na polu archeologii temat ten ostatnio przedstawiał M. Wołoszyn, Grody 
więc określić czy właśnie wówczas doszło do pierwszych kontaktów (takich, które znajdują potwierdzenie w źródłach pisanych) między Rusią, a władztwem Piastów.

Jeszcze bardziej intensywne kontakty miały miejsce w trakcie panowania kolejnej generacji Piastów i Rurykowiczów, doszło bowiem wówczas do wydania nieznanej z imienia córki Bolesława Chrobrego za syna Włodzimierza Wielkiego, Świętopełka I, o czym informował kronikarz merserburski Thietmar: Peperit haec duos filios, Miseconem et alium, quem dilecti senioris sui nomine pater vocavit, filias quoque tres, quarum una est abbatissa, II nupsit Hirimanno comiti, tercia filio regis Wlodemiri ${ }^{9}$; zaś w dalszej części: Hic tres habens filios uni eorum Bolizlavi ducis nostrique persecutoris filiam in matrimonium duxit ${ }^{10}$. Wraz z córką Bolesława Chrobrego do Kijowa wyruszył biskup kołobrzeski Reinbern ${ }^{11}$, co nastąpiło zapewne przed 1013 r. (być może $\mathrm{w} 1009$ r. $)^{12}$. Informacja ta świadczy więc wyraźnie o tym, że już wówczas dochodziło do wzajemnych kontaktów, koligacenia obu rodów panujących, a co za tym idzie, przebywania na Rusi osób, które wcześniej były związane z władztwem Piastów. Można domniemywać, że przy okazji rozmów o małżeństwie, którego dokładna data też nie jest znana, ale które zostało zawarte zapewne między 1005 a 1012 r. $^{13}$, musiały mieć miejsce rozmowy i zapewne na dwór Piastów przybywali Rusini, reprezentujący ród Rurykowiczów. Należy więc zakładać, że już wówczas dochodziło do wymiany idei, obyczajów i przedmiotów.

Kontakty rusko-polskie musiały wówczas być silne, zwłaszcza na poziomie dynastycznym, skoro pokonany przez Jarosława Mądrego „Святополкъ же бъжа в мяхы,

Czerwieńskie i problem wschodniej granicy monarchii pierwszych Piastów. Stan i perspektywy badan, [w:] Studia nad dawna Polska, t. 3, red. T. Sawicki, Gniezno 2013, s. 89-90. W odniesieniu do wyników badań historycznych najdokładniej problematykę tę omówił K. Kollinger, Polityka wschodnia, s. 267-295. Kwestię przynależności tzw. „Grodów Czerwieńskich” z szerokim uwzględnieniem tematyki czeskiej na gruncie polskiej historiografii najlepiej przedstawiła M. Matla-Kozłowska, Pierwsi Przemyślidzi i ich państwo (od X do połowy XI wieku), Poznań 2008 , s. 282-300. W opracowaniach tych czytelnik znajdzie również starszą literaturę przedmiotu.

9 Kronika Thietmara, lib IV, cap. 58, s. 227.

10 Tamże, lib VII, cap. 72, s. 571.

11 Tamże.

12 G. Labuda, Mieszko II król Polski (1025-1034). Czasy przełomu w dziejach państwa polskiego, Kraków 1992, s. 50; P. Urbańczyk, Bolesław Chrobry, s. 199.

13 Daty te zestawił K. Jasiński, Rodowód pierwszych Piastów, posł. T. Jurek, Poznań 2004 (pierwodruk z 1992), s. 121. Por. najnowsze uwagi na ten temat, których autorem jest: K. Kollinger, Polityka wschodnia, s. 35-41. 
Ярославъ же съде в Кыевъ на столь отьни и Аъани" ${ }^{14}$. Autor/autorzy Повести временных лет opisal/ te wydarzenia pod 1016 r., aczkolwiek sprawa datacji naszym zdaniem pozostaje dyskusyjna ${ }^{15}$. Wydarzenia te były ściśle związane z tym, co odnotował Thietmar pod 1013 r., który bardzo zwięźle informował o wyprawie Bolesława Chrobrego na Ruś, wskazując m.in., że Bolesława I wspierały w tym konflikcie wojska niemieckie ${ }^{16}$. Nie posiadamy niestety szczegółowych informacji o efektach tej ekspedycji poza tym, że Bolesław et magna regionis illius parte vasta$t a^{17}$. Można jednak zakładać, że najstarszy syn Mieszka I po tej wyprawie przywiózł zarówno łupy, jak i przyprowadził brańców, co bywało zresztą skutkiem większości przynajmniej częściowo udanych wypraw wojennych ${ }^{18}$. Takie zaś działania powodowały, że na terytorium władztwa Piastów trafiała obca ludność ( w tym przypadku ruska) oraz przedmioty o takowej proweniencji.

Znacznie lepiej znane są efekty kolejnej wyprawy Bolesława Chrobrego z 1018 r., o której informacje znalazły się w źródłach niemieckich, polskich i ruskich ${ }^{19}$. Efek-

\footnotetext{
14 Повесть временных лет, s. 96.

15 Problem datacji tych wydarzeń na gruncie polskiej historiografii najpełniej ostatnio omówił K. Kollinger, Polityka wschodnia, s. 159-167, wobec tego nie będziemy temu problemowi poświęcać więcej miejsca. Wypada jednak zauważyć, że zagadnienie to wymaga jeszcze w przyszłości szczegółowych rozważań i zapewne osobnego omówienia. Problematyki tej jednak szerzej nie analizujemy w tym opracowaniu, ponieważ datacja tych wydarzeń dla podejmowanych przez nas rozważań ma mniejsze znaczenie.
}

16 Kronika Thietmara, lib VI, cap. 91, s. 445.

17 Tamże.

18 Szczególnie brańcy byli wartościowym łupem, zob. H. Modrzewska, Osadnictwo jenieckie we wcześniejszym średniowieczu polskim, Kwartalnik Historii Kultury Materialnej 17 (1969), nr 3, s. 345-349, 352-353; K. Musianowicz, Guz ze wsi Morawy, pow. Radziejów, Wiadomości Archeologiczne 35 (1969), z. 3-4, s. 358-359; M. Danielewski, Struktura grodowa w drugiej połowie XI wieku. Czy lata 30. XI wieku wyznaczaja przetom dla funkcjonowania organizacji grodowej $w$ Polsce, Historia Slavorum Occidentis 2014, nr 2 (7), s. 148-149; tenże, Jedenastowieczne cmentarzysko na Morawach, Historia Slavorum Occidentis 2017, nr 4 (14), s. 25-27.

19 Kronika Thietmara, lib. VII cap. 65, s. 561, 563; lib. VIII, cap. 31-32, s. 621, 623; Galli Anonymis, lib. I, cap. 7, s. 21-25. Tekst tłumaczony Anonim tzw. Gall, Kronika polska, lib. I, cap. 7, s. 21-24; Повесть временных ^ет, s. 96-97. Nie poświęcamy większej uwagi wydarzeniom z 1017 r., kiedy to Jarosław Mądry oblegał prawdopodobnie Brześć, w którym schronił się Świętopełk, zob. Kronika Thietmara, lib. VII, cap. 65, s. 561, 563. Brześć jako cel wyprawy Jarosława Mądrego z 1017 r. wskazuје Новгородскал первал летопись младиево извода, [w: ] Новгородскал первая летопись старшево и младшево изводов, под реА. и с предисл. А.Н. Насонова, Москва - АенинграА 1950, s. 180: „Ярославъ иде къ Берестию”. Por. uwagi na ten temat autorstwa A. Poppe, Spuścizna po Włodzimierzu, s. 20. 
tem tej ekspedycji było złupienie Kijowa, wywiezienie wielkich dóbr oraz licznych jeńców (w tym wysoko urodzonych) do władztwa Piastów oraz oderwanie od Rusi tzw. „Grodów Czerwieńskich”. Najpełniej zdobycze te zostały opisane w Повести временных лет: „Болеславъ же побъже ис Кыева, възма имънье и бояры Ярославъ и сестрђ его, и Настаса пристави Аесятиньнаго ко имънью, бъ бо ся ему ввьрилъ кустью. И мюдий множьство веде с собою, и городы червеньскыя зая собъ, и приде в свою землю”20.

Pozostałe źródła również potwierdzają, że na skutek tej wyprawy do władztwa Piastów płynęly m.in. liczne skarby oraz brańcy:

Ibi fuit noverca regis predicti, uxor et VIIII sorores eiusdem, quarum unam prius ab eo desideratam antiquus fornicator Bolizlavus oblita contectali sua iniuste duxerat. Ineffabilis ibi pecunia ei ostenditur, cuius magna pars hospitibus suis ac fautoribus distribuitur, quedam vero ad patriam mittitur ${ }^{21}$.

Igitur rex Bolezlauus urbe ditissima regnoque Ruthenorum potentissimo decem mensibus potitus, inde pecuniam in Poloniam transmittendo nunquam extitit otiosus; undecimo vero mense, quia regna quam plurima tenebat et puerum ad regnandum Meschonem adhuc ydoneum non videbat, loco sui quodam ibi Rutheno sui generis in dominum constituo, cum thezauro residuo Poloniam remeabat ${ }^{22}$.

Dane te wystarczają do stwierdzenia, że wówczas musiało dochodzić do napływu ludności ruskiej i tamtejszych wyrobów na ziemie władztwa Piastów, wobec czego należałoby oczekiwać śladów tych kontaktów szczególnie w kulturze materialnej czy nazewnictwie miejscowym, które może być dowodem osiedlania ruskich brańców. Do kwestii tej jeszcze wrócimy w dalszej partii opracowania.

Problem brańców, tym razem polskich, jest także interesujący w kontekście panowania Mieszka II i lat trzydziestych XI w. Z zapisów źródłowych ruskich wiemy, że w 1030 r. „Ярославъ Бемзы взялъ”23, a już rok później ten sam książę wraz z Mścisławem Chrobrym, księciem czernichowskim „собраста вой многъ, идоста на $\Lambda$ ях, и заяста грады червеньскыя опять, и повоеваста $\Lambda$ яьскую землю, и многы мяхы приведоста, и раздьливша я. Ярославъ посади своя по Ръси, и суть до сего Ане”24.

\footnotetext{
20 Повесть временных лет, s. 97.

21 Kronika Thietmara, lib. VIII, cap. 32, s. 621, 623.

22 Galli Anonymi, lib. I, cap. 7, s. 23. Tekst tłumaczony Anonim tzw. Gall, Kronika polska, lib. I, cap. 7, s. 22.

23 Повесть временных лет, s. 101.

24 Tamże.
} 
Ponownie więc w opisie źródłowym występują tzw. „Grody Czerwieńskie”, ale co jeszcze bardziej interesujące, znów pojawia się problem brańców i osadzania ich na terenie własnego władztwa, w tym przypadku Rusi. Sądzę, że właśnie te przesiedlenia ludności musiały w znaczącym stopniu skutkować obecnością obcych kulturowo treści w domenach Rurykowiczów i Piastów.

Wspominaliśmy już wyżej o kontaktach na poziomie rodzin książęcych obu władztw m.in. o koligacjach dynastycznych - małżeństwo nieznanej z imienia córki Bolesława Chrobrego i Emnildy ze Świętopełkiem I - i pobycie tego ruskiego księcia $\mathrm{w}$ domenie Piastów ${ }^{25}$. Wiemy jednak ze źródeł, że również Bezprym, pierworodny syn Bolesława Chrobrego, przebywał na dworze ruskim. O wydarzeniu tym informował prezbiter cesarskiej kapeli Wipon ${ }^{26}$, myląc akurat najstarszego syna Bolesława Chrobrego z Ottonem Bolesławowicem: Misico dum fratrem suum Ottonem persequeretur, expulerat eum in Ruzziam. Dum ibi aliquantum tempus miserabiliter viveret, coepit rogare gratiam imperatoris Chuonradi, ut ipso impetrante et iuvante restitueretur patriae suae ${ }^{27}$.

Z powyższych zapisów źródłowych wyraźnie więc wynika, że wzajemnie kontakty między domenami Piastów i Rurykowiczów były w omawianym okresie dość intensywne. Jednocześnie charakteryzowały się one dużym zróżnicowaniem. W związku z tym pozostaje się więc zastanowić, czy kontakty te znajdują odzwierciedlenie $\mathrm{w}$ materiale toponomastycznym oraz archeologicznym.

\section{Nazewnictwo miejscowe}

Wspominaliśmy już wyżej na podstawie zapisów źródłowych, że brańcy ruscy trafiali do władztwa Piastów. Kolejnym śladem ich obecności jest bogate nazewnictwo

25 Pobyt ten z pewnością miał miejsce, dyskusyjne pozostaje jednak, kiedy dokładnie Świętopełk I przebywał w Polsce. Por. K. Jasiński, Rodowód pierwszych Piastów, s. 122; K. Kollinger, Polityka wschodnia, s. 371-375; tenże, Odkrycia w Bodzi w kontekście wydarzeń na Rusi przetomu I i II tysiąclecia, [w:] Bodzia. Elitarny cmentarz z początków państwa polskiego, red. A. Buko, Warszawa 2016, s. 47. Por. A. Poppe, Świętopetk I, [w:] SSS, t. 5, red. G. Labuda, Z. Stieber, Wrocław 1975, s. 570.

26 Szczegółowa charakterystyka Wipona i jego dzieła w: J. Sochacki, Wstęp, [w: ] Gesta Chuonradi II impreratoris, Kraków 2005, s. IX-XXV.

27 Gesta Chuonradi II, cap. 29, s. 110. Na temat tej pomyłki szerzej wypowiadał się w ostatnich latach B. Śliwiński, Bezprym. Pierworodny syn pierwszego króla Polski (986 - zima/wiosna 1032), Kraków 2014, s. 195, a w starszej literaturze przedmiotu D. Borawska, Kryzys monarchii wczesnopiastowskiej w latach trzydziestych XI wieku, Warszawa 1964, s. 78-80. 
miejscowe, na które najpełniej zwróciła uwagę Halina Modrzewska. Wśród nazw, które przypisywała ona obecności ludności ruskiej w domenie Piastów, można wymienić: Rusaki, Rusek, Rusibórz, Rusiniec, Rusinów, Rusinowice, Rusko, Rusów ${ }^{28}$. Oczywiście, należy mieć świadomość, zresztą podobnie jak w przypadku tzw. odsłużebnych nazw miejscowych, że cześć z nich mogła mieć genezę znacznie młodszą ${ }^{29}$. Co jednak ciekawe, nazwy miejscowe, które z mniejszym lub większym prawdopodobieństwem można by wiązać z ludnością ruską osadzoną na terenie Wielkopolski lub Kujaw, nie występują zbyt licznie. H. Modrzewska dla tego obszaru władztwa Piastów odnotowuje zaledwie kilka toponimów (Rusowo, Ruszków, Rusinowo, Rusiec, Rusinowice, Ruszcza), które według niej mogą pochodzić od brańców ruskich $^{30}$. Jednocześnie autorka wyraźnie zaznacza, że poszukiwanie nazw miejscowych na terenie Polski, które można by identyfikować z ludnością ruską, powinno być nacechowane ostrożnością, ponieważ rdzeń Rus-Ruś charakteryzuje się dużą wieloznacznością i brakuje dla obszaru władztwa Piastów czystych form: Ruś, Rusy czy Rusiny, pochodzących od wspominanego wyżej rdzenia. Na omawianym obszarze występują więc tylko odmiany rdzenia Rus-Ruś w postaci nazw dzierżawczych ${ }^{31}$. Część z tych wymienionych wyżej toponimów ma oczywiście metrykę sięgającą XIII czy XIV w., jednak zasadne pozostaje pytanie, czemu w przypadku domniemanych nazw miejscowych pochodzących od brańcow ruskich nie spotykamy form Ruś Rusy czy Rusiny, tak jak to analogicznie obserwujemy w odniesieniu do pomorskiej ludności jenieckiej (Pomorze - Pomorzany) czy jeńców z południa (Morawy

28 H. Modrzewska, Osadnictwo jenieckie, s. 362. Problem osadnictwa jenieckiego był w literaturze przedmiotu wielokrotnie poruszany, wobec tego prezentujemy tylko wybraną literaturę przedmiotu, w której czytelnik znajdzie dalsze wskazówki bibliograficzne: H. Modrzewska, Osadnictwo obcoetniczne i innoplemienne w Polsce wcześniejszego średniowiecza, Warszawa 1984; M. Szyszkiewicz-Moroz, Nazwy etnonimiczne jako pomocnicze źródło historyczne do badań nad osadnictwem tatarskim na przykładzie powiatu grodzieńskiego (do 1795 r.), Studia Podlaskie 4 (1993), s. 156-157; W. Urban, J. Rajman, Węgrzy pod Krakowem we wczesnym średniowieczu, Przegl. Hist. 85 (1994), nr 3, s. 279-285; M. Florek, Osadnictwo grup ludności $z$ terenu Wegier w Małopolsce i na Rusi Halickiej w XI-XIII w. w świetle źródet archeologicznych i topomastycznych, [w:] Wczesne średniowiecze w Karpatach polskich, red. J. Gancarski, Krosno 2006, s. 731-736; M. Danielewski, The early medieval village of Morawy: a grave field from the $11^{\text {th }}$ century, Slavia Antiqua 58 (2017), s. 117-118.

29 Por. M. Danielewski, Sieć grodowa na Kujawach oraz jej funkcje od połowy X do końca XIII wieku, Poznań 2016, s. 204-205 (przyp. 178).

H. Modrzewska, Osadnictwo jenieckie, s. 363-364, ryc. 1.

31 Tamże, s. 362-363. 
- Morawiany, Morawce). Wspominana już wyżej H. Modrzewska wskazywała dwa wyjaśnienia tego problemu. Po pierwsze, uczona sądziła, że brak form Rusy, Rusiny może wynikać ze zmiany sufiksów przy rdzeniu Ruś, co mogło oczywiście nastąpić na przestrzeni dziejów ${ }^{32}$. Po drugie, autorka wskazywała na problem wykupowania czy częstego zwracania jeńców ruskich ${ }^{33}$.

O ile pierwsze wyjaśnienie wydaje się dość prawdopodobne, o tyle drugie jest co najmniej dyskusyjne. Jest faktem, że w Повести временных ^ет znajdujemy zapis: „и вАасть Казимиръ за въно мюдий 8 сотъ, яже бъ полонилъ Болеславъ, победив Ярослава" ${ }^{34}$, z którego jasno wynika, że niekiedy zwracano brańców. Wspominany wyżej zapis odnosi się już do panowania na tronie piastowskim Kazimierza Odnowiciela i jego ślubu z siostrą Jarosława Mądrego, Dobroniegą, ale ewidentnie nawiązuje do wydarzeń z czasów panowania Bolesława Chrobrego ${ }^{35}$. Trudno jednak sądzić na podstawie tej jednej zapiski, że zwrócono wówczas Jarosławowi Mądremu wszystkich ruskich brańców, których zabrał ze sobą Bolesław Chrobry po zwycięstwach nad Rusią. Można zakładać, że Kazimierz Odnowiciel w ramach zawartego najpewniej w 1042 r. małżeństwa ${ }^{36}$ zwrócił Jarosławowi Mądremu znaczącą grupę brańców ruskich ${ }^{37}$. Trudno jednak na tej podstawie twierdzić, że wszyscy dawni jeńcy i ich potomkowie wrócili do władztwa Rurykowiczów, zwłaszcza że ostatni najazd Bolesława Chrobrego na Ruś (1018 r.) i omawiane wydarzenia z czasów panowania Kazimierza Odnowiciela (1043 r.) dzieliło aż 25 lat. Z kolei od pierwszej wyprawy Bolesława I na Ruś (1013 r.) do przywołanych wydarzeń z lat czterdziestych XI w. minęło jeszcze więcej, bo aż 30 lat. Można więc stwierdzić, że przez ten okres czasu w dorosłość wkroczyły dwa pokolenia dzieci wspominanych wyżej ruskich brańców ${ }^{38}$. Jeśli do tego dodamy, że średnia życia

\footnotetext{
32 Tamże, s. 362.

33 Tamże.

34 Повесть временных ^ет, s. 104.
}

35 Wydarzenia te, wraz z prezentacją problemu pomocy ruskiej dla Kazimierza Odnowiciela walczącego z Miecławem, omówili całościowo m.in. J. Bieniak, Państwo Miecława, s. 123-141; S. Kętrzyński, Kazimierz Odnowiciel, s. 61-62, 72-75, 95.

36 J. Bieniak, Państwo Miectawa, s. 134. Inaczej uważała K. Dróżdż, Kazimierz Odnowiciel. Polska w okresie upadku i rozbudowy, Wodzisław Śląski 2009, s. 94-95, która wskazywała, że być może jeszcze przed $1040 \mathrm{r}$. doszło do zawarcia tego małżeństwa. W pracach tych czytelnik znajdzie również pełne omówienie literatury przedmiotu dotyczące tej problematyki.

37 Zwrot brańców miał nastąpić w 1043 r., zob. Повесть временных лет, s. 104.

38 Przyjmujemy, że we wczesnym średniowieczu osoba w wieku mniej więcej 14 lat (dla chłopców) i 12 lat (dla dziewczynek) stawała się dorosłą, a więc w pełni sprawną do ożenku i zakładania rodziny, zob. M. Delimata, Dziecko w Polsce średniowiecznej, Poznań 2004, s. 29-35, 
dorosłych sięgała około 30 lat ${ }^{39}$, to wypada sądzić, że znacząca część osób, które stały się jeńcami w trakcie wypraw Bolesława Chrobrego na Ruś i które trafiły do władztwa Piastów, w latach czterdziestych XI już nie żyła. Wreszcie warto zauważyć, że jeśli liczby podane w Повести временных ıет są prawdziwe ${ }^{40}$ oraz zakładając, iż mała rodzina liczyła między 5 a 8 osób ${ }^{41}$, to wówczas zapis „Аюдий 8 сотъ” ${ }^{42}$ odnosiłby się do 100 -160 rodzin. Liczby te znów można orientacyjnie przeliczyć na ilość wsi, które ludność taka musiałaby zamieszkiwać. W okresie przed kolonizacją niemiecką poszczególne wsie liczyły po kilka, przeciętnie 5-6 rodzin ${ }^{43}$. Gdyby uznać, że 8 osób składało się na jedną rodzinę, to musielibyśmy stwierdzić, że około 800 osób stanowiło około16-20 wsi. Niemniej od razu należy zaznaczyć, że na pewno brańcy ruscy z wypraw Bolesława Chrobrego nie zamieszkiwali tylko wsi, część z nich (zwłaszcza ci z możnych rodzin ruskich) mogła przebywać w otoczeniu władcy, pełniąc różnorakie role, inni żyli w grodach czy osadach podgrodowych, zajmując się rzemiosłem; dalsi mogli zasilić szeregi służebników książęcych. Oczywiście, nie sposób ustalić, jaka liczba jeńców ruskich trafila do władztwa Piastów w trakcie wypraw Bolesława Chrobrego. Jesteśmy jednak przekonani, że owe 800 osób, a więc 100-160 rodzin, nie mogło stanowić wszystkich ruskich brańców osadzonych w domenie Piastów. Jeśli do tego dodamy fakt, że w drugiej połowie XI w., za panowania Bolesława Szczodrego, również dochodziło do

166-169 (zwłaszcza s. 166-167); Rodzina i dziecko w średniowieczu, Poznań 2017 (folder wystawy z Rezerwatu Archeologicznego Genius Loci), s. 10.

39 J. Tyszkiewicz, Chrześcijaństwo $w$ rodzinie polskiej do połowy XIII w., [w:] Ecclesia regnum fontes. Studia z dziejów średniowiecza, red. S. Gawlas, K. Gołąbek, M.A. Janicki, R. Michałowski, M. Piber-Zbieranowska, P. Węcowski, Warszawa 2015, s. 64. Por. tenże, Ludzie i przyroda $w$ Polsce średniowiecznej, Warszawa 1983, s. 160-182 (zwłaszcza s. 177), gdzie znalazły się szerokie rozważania na temat demografii ziem polskich w średniowieczu.

40 Kwestia prawidłowej liczby tych niewolnych pozostaje jednak dyskusyjna, zob. S.M. Kuczyński, Studia z dziejów Europy Wschodniej X-XVII w., Warszawa 1965, s. 120.

41 W tym przypadku opieramy się na przykładzie wyników badań odnoszących się do wielkopolskiego cmentarzyska z Dziekanowic (stanowisko nr 22), gdzie można mówić o tej wielkości (5-8 osób) małych rodzin, zob. A. Wrzesińska, Odtworzenie stanu i dynamiki biologicznej ludności pochowanej na cmentarzysku wczesnośredniowiecznym Dziekanowice, stanowisko 22, Studia Lednickie 5 (1998), s. 29-40, zwłaszcza s. 36. Por. uwagi na temat demografii rodzin: J. Tyszkiewicz, Ludzie i przyroda, s. 160-187; Rodzina i dziecko, s. 3.

42 Повесть временных лет, s. 104.

43 K. Modzelewski, Chłopi w monarchii wczesnopiastowskiej, Wrocław 1987, s. 29. Por. Z. Podwińska, Zmiany form osadnictwa na ziemiach polskich we wcześniejszym średniowieczu. Źreb, wieś, opole, Wrocław 1971, s. 149-157. 
wypraw na Ruśs ${ }^{4}$, a ich skutkiem musiało być sprowadzanie do władztwa Piastów obcej ludności, to nie sposób uznać, iż właśnie zwracanie jeńców (wyżej wspominana informacja z Повести временных ^ет) mogło prowadzić do nieutrwalania się jenieckiego nazewnictwa miejscowego, które byłoby jednoznacznie związane z rdzeniem Rus/Ruś. W tej sytuacji uważamy, że brak form Rusy, Rusiny w nazewnictwie miejscowym obszaru władztwa Piastów wynika najpewniej ze zmiany sufiksów przy rdzeniu Rus/Ruś.

W związku z powyższymi ustaleniami wypada zwrócić uwagę na odmiany rdzenia Rus/Ruś w postaci nazw dzierżawczych. W tym przypadku znów z pomocą przychodzą rozważania H. Modrzewskiej, która dla Wielkopolski i Kujaw wyliczyła przynajmniej sześć tego rodzaju nazw miejscowych, o których informowano już w źródłach pisanych z okresu średniowiecza. Na obszarze Wielkopolski autorka odnotowuje: Russów (Russowo) pod Kaliszem ${ }^{45}$, Ruszków (Rusichow) z okolic Koła ${ }^{46}$, Rusinowo osada zanikła spod Kościana ${ }^{47}$, dalej Rusiec (Russecz), położony w rejonie Wągrowca ${ }^{48}$ i Rujsca $($ Ruscha $)$ z rejonu Kostrzyna Wielkopolskiego ${ }^{49}$; z kolei dla Kujaw - Rusinowo $(\text { Russinowo })^{50}$. Jednak już w tym miejscu należy podkreślić, że nie jest to pełna lista

44 Kwestie te szczegółowo omawiali: T. Grudziński, Bolesława Szczodry, s. 97-111; tenże, Bolesław Śmiaty-Szczodry, psassim; N. Delestowicz, Bolesław II Szczodry, s. 119-136, 250-263. Problematyka tych wypraw nie będzie elementem naszych dalszych badań.

45 Autorka nazwę tę zapisała jako Rusów, zob. H. Modrzewska, Osadnictwo jenieckie, s. 363. Natomiast obecna nazwa tej wsi, którą my podajemy, to Russów. Russowo w źródłach pisanych pojawia się już pod 1282 r., zob. Kodeks dyplomatyczny Wielkopolski, t. I, wyd. I. Zakrzewski, Poznań 1877, nr 511.

46 H. Modrzewska, Osadnictwo jenieckie, s. 363. Osada ta pojawia się po raz pierwszy w źródłach pisanych pod 1285 r., zob. Dokumenty kujawskie i mazowieckie przeważnie z XIII wieku, wyd. B. Ulanowski, Kraków 1887, s. 112 (nr 46).

47 H. Modrzewska, Osadnictwo jenieckie, s. 363. Osada wzmiankowana pod 1413 r., zob. K.J. Hładyłowicz, Zmiany krajobrazu i rozwój osadnictwa w Wielkopolsce od XIV do XIX wieku, przedm. F. Bujak, Lwów 1932, s. 172.

48 Rusiec wzmiankowano w 1399 r. zob. H. Modrzewska, Osadnictwo jenieckie, s. 363. Por. uwagi następującego autora: S. Kozierowski, Badania nazw topograficznych na obszarze dawnej zachodniej i środkowej Wielkopolski, t. 2, Poznań 1922, s. 260.

49 Autorka nazwę tę podała jako Ruszcza, ponieważ tak tę nazwę miejscowości również zapisywano, zob. tamże. Por. Stownik geograficzny Królestwa Polskiego i krajów słowiańskich, red. B. Chlebowski, W. Walewski, t. 10, Warszawa 1889, s. 37. Ruscha w źródłach pisanych pojawia się po raz pierwszy w 1218 r., zob. Kodeks dyplomatyczny Wielkopolski, t. I, nr 104.

50 H. Modrzewska, Osadnictwo jenieckie, s. 363. Por. S. Kozierowski, Badania nazw topograficznych, t. 2, s. 261. Russinowo wymienione zostało już w 1381 r., zob. Kodeks dyplomatyczny Wielkopolski, t. 3, wyd. I. Zakrzewski, Poznań 1879, nr 1789. 
toponimów z terenu Wielkopolski i Kujaw, które można podejrzewać o pochodzenie od ruskiej ludności niewolnej. Najlepszym przykładem na potwierdzenie tych słów są Kujawy, gdzie w sumie funkcjonowało w okresie średniowiecza aż pięć nazw miejscowych (wliczając w tę liczbę wcześniej wspomniane Russinowo), które można wstępnie zaliczyć do omawianej kategorii osad, są nimi: Ruszki (okolice Kościelnej Wsi), Ruszki (zaginiona osada pod Chodczem), Ruszkowo i Ruszkówek (rejon Sompolna) ${ }^{51}$. Gdyby więc przyjąć kryterium nazewnicze z odmianą rdzenia Rus/Ruś w postaci nazw dzierżawczych, to liczba tzw. osad jenieckich związanych z ludnością ruską byłaby znacząca. Uważamy jednak, że bez pogłębionych studiów językoznawczo-osadniczych nie sposób jednoznacznie wskazać, które osady mogą rzeczywiście być śladem obecności omawianych brańców. Jednocześnie sądzimy, że podjęcie w przyszłości całościowych badań tego rodzaju może przyczynić się do poszerzenia naszej wiedzy na temat ruskiego osadnictwa jenieckiego.

\section{Źródła archeologiczne ${ }^{52}$}

Omawiany materiał ma nieco inną specyfikę, niż prezentowane wcześniej źródła pisane czy nazwy miejscowe o domniemanym jenieckim pochodzeniu. W tym przypadku każdorazowo mamy do czynienia artefaktami, na podstawie których możemy wnioskować o istnieniu kulturowych kontaktów polsko-ruskich i dopiero opierając się na tych analizach rozważać, czy obecność danych przedmiotów świadczy o wędrówce rzeczy, idei czy jednak ludzi. Źródła pisane zdecydowanie częściej informują o wędrówce ludzi niż przedmiotów czy idei, podczas gdy archeologiczne raczej dostarczają danych o wędrówce rzeczy, niekiedy idei, a bardzo rzadko ludzi. Ta zasadnicza różnica między tymi dwoma kategoriami historycznego materiału źródłowego powoduje, że źródła te analizowane razem dobrze się uzupełniają. Nie pozostaje więc nic innego, jak zwrócić baczniejszą uwagę na wyniki badań archeologicznych.

51 S. Kozierowski, Badania nazw topograficznych, t. 2, s. 262; Księgi sądowe brzesko-kujawskie 1418-1424, wyd. J.K. Kochanowski, Warszawa 1905, s. 322 (nr 3166); J. Senkowski, Lustracja poradlnego i rejestr łanów województw brzesko-kujawskiego i inowrocławskiego z roku 1489, Teki Archiwalne 7 (1961), s. 144; A. Pawiński, Sejmiki ziemskie. Dodatki, Warszawa 1895, XXXIII (nr 101); Stownik geograficzny, t. 10, s. 38.

52 Omawiamy tylko wybrane źródła archeologiczne, albowiem wiele z interesujących nas materiałów odnosi się do młodszego horyzontu czasowego niż ten, którym się zajmujemy. Spieszymy jednak też dodać, że niektóre z artefaktów, których poniższe rozważania dotyczą, mają znacznie szerszą chronologię niż ta podana w tytule artykułu. Zwykle jednak ich dolna granica chronologiczna odnosi się do okresu X - pierwsza połowa XI w. 
W tym przypadku materiał zabytkowy, który w literaturze przedmiotu starano się interpretować jako element kontaktów polsko-ruskich, został dość skrupulatnie omówiony nie tylko w odniesieniu do interesującej nas Wielkopolski oraz $\mathrm{Kujaw}^{53}$. Wobec tego nie będziemy szczegółowo prezentować konkretnych zabytków, a jedynie wskażemy, które z nich występują na omawianym obszarze i jakie mogą one mieć znaczenie dla rozważań nad wpływami ruskimi we władztwie Piastów.

Pierwszą kategorią artefaktów, które nas interesują, są miniaturowe toporki. Przedmioty te uznano generalnie za importy z Rusi (Europy Wschodniej) ${ }^{54}$, co nie może dziwić w kontekście tego, że większość $\mathrm{z}$ nich była odnajdywana na terenach ruskich $^{55}$. Również na obszarze Wielkopolski (Dziekanowice, Kalisz i Poznań) ${ }^{56}$ oraz Kujaw (Kruszwica i Sędzin) ${ }^{57}$ przedmioty te były odkrywane. Niewykluczone, że miniaturowe toporki były symbolem wojowników, członków drużyny książęcej ${ }^{58}$, co akurat wydaje się bardzo interesujące w kontekście czynionych przez nas rozważań.

Innymi znaleziskami, które mają konotacje wschodnie, są odkryte na Ostrowie Lednickim elementy łuków refleksyjnych, a były nimi płytki wykonane z kości lub poroża ${ }^{59}$. Zabytki te mają dość szeroką chronologię i próbowano je w dotychczasowej

53 Literatura ta była już prezentowana we wstępie tegoż artykułu.

54 M. Wołoszyn, Zabytki pochodzenia wschodniego, s. 252-253; tenże, Ze studiów, s. 596-597; R. Liwoch, Importy staroruskie w Polsce przykłady ze zbiorów dawnych Muzeum archeologicznego w Krakowie, [w:] Micma Аавньої Pyci, red. П.П. Толочко, Київ 2014, s. 416-417.

55 P. Kucypera, P. Pranke, S. Wadyl, Wczesnośredniowieczne toporki miniaturowe, Toruń 2011, s. 33 (mapa 3), 55-63, 77-105.

56 A. Wrzesiński, J. Wrzesiński, Grób z miniaturowym toporkiem z Dziekanowic, stan. 22, gm. Łubowo, woj. poznańskie, Wielkopolskie Sprawozdania Archeologiczne 4 (1996), s. 197-204; A. Dębski, H. Kóčka-Krenz, Militaria z Ostrowa Tumskiego w Poznaniu, Archaeologia Historica Polona 17 (2007), s. 58-59; A. Kędzierski, D. Wyczółkowski, Toporki miniaturowe z badań na Starym Mieście w Kaliszu, Wielkopolskie Sprawozdania Archeologiczne 15 (2014), s. 95-105.

57 B. Hensel-Moszczyńska, Miniaturowy toporek z Kruszwicy, Slavia Antiqua 26 (1979), s. 127-130; taż, Wyroby z miedzi i jej stopów z wczesnośredniowiecznej Kruszwicy, Slavia Antiqua 28 (1983), s. 171-172; J. Maik, Sędzin st. 86 i 87, gm. Zakrzewo, woj. wtocławskie, AZP 46-43/252 i 253, Informator Archeologiczny. Badania 1997 (2006), s. 270-271.

58 M. Wołoszyn, Ze studiów, s. 601-602.

59 Omówienie tego znaleziska czytelnik znajdzie w pracy następujących autorów: P. Dmochowski, J. Wrzesiński, W poszukiwaniu łuku refleksyjnego - możliwości interpretacji na przykładzie znaleziska $z$ Ostrowa Lednickiego, [w: ] Wędrówki rzeczy i idei w średniowieczu, red. S. Moździoch, Wrocław 2004, s. 313-328. W sumie na Ostrowie Lednickim odkryto dwie tego typu płytki, z czego pierwsza była wykonana najpewniej z poroża, a w przypadku drugiej surowca nie określono, zob. tamże, s. 325-316, 327-328. 
literaturze przedmiotu wiązać z obecnością na wczesnośredniowiecznym Ostrowie Lednickim wojowników ze wschodu ${ }^{60}$. Jednak należy przy tej interpretacji zauważyć, że łuk refleksyjny typowy jest również dla społeczeństw nomadycznych, a pewną część znalezisk czy wyobrażeń tego elementu uzbrojenia (w konstrukcji kompozytowej) należy wiązać z takimi ludami ${ }^{61}$. Szczególnie liczne są także znaleziska fragmentów tego typu łuków pochodzące z terenów wczesnośredniowiecznej Rusi ${ }^{62}$. Trudno jednak na tej postawie jednoznacznie stwierdzić, czy omawiane płytki (elementy łuków refleksyjnych) odkryte na terenie Wielkopolski były przedmiotami pochodzącymi ze wschodu (może z Rusi), czy jednak z południa. Należy bowiem zauważyć, że łuków refleksyjnych używali nie tylko Rusini, wschodni nomadzi - Pieczyngowie, ale także Węgrzy (również w okresie stabilizacji osadniczej) ${ }^{63}$. Niemniej za słusznością poglądu o wschodniej proweniencji płytek lednickich mogą przemawiać właśnie analogie w ornamentyce do tego typu przedmiotów ze wschodu Europy ${ }^{64}$.

Kolejnym elementem uzbrojenia, który jest być może świadectwem kontaktów polsko-ruskich, są tzw. szyszaki wielkopolskie, będące kategorią helmów segmentowych. W polskiej literaturze przedmiotu na temat wspominanych wyżej hełmów oraz pochodzenia tego rodzaju uzbrojenia toczyła się żywa dyskusja już przed drugą wojną światową ${ }^{65}$. Przypomnijmy, że na terenie Wielkopolski odkryto aż cztery tego typu hełmy (Giecz, Gniezno, Gorzuchy, Olszówka) ${ }^{66}$ i próbowano nawet sugerować, że są one elementem miejscowej wytwórczości ${ }^{67}$. We współczesnej literaturze przedmiotu

60 Tamże, s. 325-328. Por. M. Wołoszyn, Ze studiów, s. 595-596.

61 P. Dmochowski, J. Wrzesiński, W poszukiwaniu łuku, s. 319-322; M. Bogacki, Broń wojsk polskich $w$ okresie średniowiecza, Poznań 2009, s. 69-70. Por. J. Werner, Polska broń. Euk i kusza, Wrocław 1974, s. 15-16, 21.

62 А.Ф. Меаведев, Ручное метательное оружие. Аук и стрелы. Самострел VIII-XIV вв, Москва 1966, passim; K.A. Mikhailov, S.Y. Kainov, Finds od structural details of composite bows from ancient Rus, Acta Archaeologica Academiae Scientiarum Hungaricae 62 (2011), s. 229-242.

63 K. Sebestyén, A sagittis Hungarorum”. A magyarok ijja és nyila. Bogen und Pfeilder alten Ungarn, Dolgozatok 8 (1932), s. 167-255; A. Dragotă, Suita militară din necropola de la Alba Iulia Izvorul Împăratului (sec. X), Transilvania 8 (2018), s. 70.

64 P. Dmochowski, J. Wrzesiński, W poszukiwaniu łuku, s. 328.

65 Z. Bocheński, Polskie szyszaki wczesnośredniowieczne, Karków 1930; tenże, Nowe materiały do zagadnienia polskich szyszaków wczesnośredniowiecznych, Sprawozdana Polskiej Akademii Umiejętności 11 (1935), nr 9, s. 319-321; W. Sommerfeld-Sarnowska, O tzw. „polskich” szyszakach wczesnośredniowiecznych, Wiadomości Archeologiczne 16 (1939), s. 316-320.

66 Tamże, s. 319.

67 Z. Bocheński, Polskie szyszaki. 
wyraźnie jednak wskazuje się, że hełmy te (a przynajmniej ich formy wyjściowe) pochodzą ze wschodu, a konkretnie z Rusi ${ }^{68}$. Kwestię tę zasadniczo rozstrzygają analogie, tego typu hełmy segmentowe w znaczącej liczbie odkrywano na terenach ruskich (m.in.: Czarna Mogiła pod Czernichowem, Gniezdowo, Gułbiszcze, Kijów, Mokre, Tuapse, Woroneż $)^{69}$. Szyszaki odkryte w Wielkopolsce wykazują się szczególnie bliskimi analogiami do hełmu z Czarnej Mogiły ${ }^{70}$. Bardzo interesujące musi wydawać się to, że szłomy wielkopolskie są datowane na koniec X-początek XI w., tymczasem najstarsze tego typu znaleziska z terenów ruskich pochodzą już z IX stulecia, a również z X, XI i początków XII w. są stamtąd znane omawiane hełmy segmentowe ${ }^{71}$. Wobec powyższych spostrzeżeń można założyć, że omawiany rodzaj szyszaków trafił na teren władztwa Piastów właśnie z Rusi. Nie sposób jednak stwierdzić, czy były one importem, zdobyczą wojenną czy może śladem obecności wojowników ruskich w drużynie piastowskiej ${ }^{72}$.

Surowcem, który z pewnością był sprowadzany na teren władztwa Piastów z Rusi jest łupek owrucki (wołyński), z którego przede wszystkim wykonywano przęśliki ${ }^{73}$. Jest on bardzo częstym znaleziskiem na terenie władztwa Piastów. Przęśliki z tego ma-

68 M. Bogacki, Broń wojsk polskich, s. 92. Por. A. Nadolski, Studia nad uzbrojeniem polskim $w$ X, XI, XII wieku, Łódź 1954, s. 71-75, gdzie autor podsuwa dwa rozwiązania pochodzenia hełmów. W ramach pierwszego z nich szłomy odkryte na ziemiach polskich miałyby pochodzić z Rusi Kijowskiej i być elementem handlu. Według drugiego rozwiązania produkowano je na miejscu, we władztwie Piastów.

69 W. Sommerfeld-Sarnowska, O tzw. „polskich” szyszakach, s. 316-320.

70 А.Н. Кирпичников, Руские илемы Х-ХІІІ вв., Советскал Археологиа 1958, nr 4, s. 56-58. Autor dwanaście hełmów segmentowych odkrytych na terenie Rusi, Polski, Prus i Węgier określa typem „Czarnej Mogity”.

71 W. Sommerfeld-Sarnowska, O tzw. „polskich” szyszakach, s. 318-319. Pełną listę znalezisk hełmów z terenów ruskich zaprezentował A.Н. Кирпичников, Руские илемы, s. 47-69, отаwiając przy tym interesujący nas rodzaj hełmów segmentowych (s. 48-59).

72 Omawiane szyszaki jako łup wojenny Bolesława Chrobrego chciała widzieć W. Sommerfeld-Sarnowska, O tzw. „polskich” szyszakach, s. 320. Michał Bogacki sugerował, że być może Bolesław Chrobry uprowadził w 1018 r. z Rusi rzemieślników, którzy zaczęli na miejscu w Wielkopolsce produkować tego typu hełmy, zob. tenże, Broń wojsk polskich, s. 92. Wreszcie Stanisław Zakrzewski wskazywał, że hełmy te są elementem kontaktów z Pieczyngami, zob. tenże, Bolesław Chrobry Wielki, Lwów-Warszawa-Kraków 1925, s. 196.

73 Na ten temat szerzej wypowiadano się następujących pracach: M. Michalik, S.V. Pavlenko, M. Paszkowski i A.P. Tomaševski, Wyroby uznawane za wykonane z tupku owruckiego w Europie Środkowej i Pótnocnej - import czy wyrób lokalny?, [w:] Fundacja na Rzecz Nauki Polskiej dla archeologii. Podsumowanie programów TRAKT i ARCHEO, red. M. Łańczont, J. Nogaj-Chachaj, Lublin 2003, s. 55-58; R. Liwoch, Importy staroruskie, s. 415-416. 
teriału były wytwarzane na Rusi już przed połową X w., zaś schyłek tej produkcji jest związany z końcem XIII-XIV w. ${ }^{74}$ Przęśliki z łupku owruckiego odnajdywano również na terenie Wielkopolski i Kujaw w takich wczesnośredniowiecznych ośrodkach, jak: Gniezno, Kalisz, Kruszwica, Międzyrzecz, Poznań, Ostrów Lednicki ${ }^{75}$, czy na ówczesnych cmentarzyskach ${ }^{76}$. Można zastanawiać się, czemu surowiec ten tak szeroko rozprzestrzeniał się w Europie Środkowej i Wschodniej ${ }^{77}$. Marcin Wołoszyn wskazuje na kontakty handlowe, ale równie mocno akcentuje wędrówkę ludzi. Uczony podkreśla przy tym, że to domeną kobiet było przygotowywanie odzieży, wobec tego przęśliki stanowiły najczęściej ich własność - niewykluczone więc, iż przedmioty te rozprzestrzeniały się wraz z ich właścicielkami wydawanymi za mąż ${ }^{78}$. Być może należy także

74 С. Терський, Ао проблеми датування археологічного матеріалу періоду Галицько-Волинської держави, Наукові записки АИМ 10 (2001), s. 142, 145; А.В. Петраускас, Ремесла та промисли сільського населення Середнього Подніпров'я в IX-XIII cm., Київ 2006, s. 82; R. Liwoch, Importy staroruskie, s. 415.

75 J. Kostrzewski, Najstarsze Gniezno w świetle wykopalisk, Przegląd Zachodni 3 (1947), nr 4, s. 316; A. Cofta-Broniewska, Sprawozdanie z badań wykopaliskowych w Kruszwicy w latach 1956 i 1957, Sprawozdania Archeologiczne 11 (1960), s. 64, 65; Tu powstała Polska. Katalog wystawy stałej $w$ Muzeum Archeologicznym w Poznaniu, red. M. Brzostowicz, A. Stempin, Poznań 2009, s. 24, 44, 46; B. Banach, Zabytki wydzielone z warstw wczesnośredniowiecznych grodu i podgrodzia (stan. 1 i 1a), [w:] Międzyrzecz. Gród i zamek w wiekach IX-XIV. Wyniki prac wykopaliskowych z lat 1951-1961, red. S. Kurnatowski, Warszawa 2015, s. 296; A. Kędzierski, D. Wyczółkowski, Stare Miasto Kalisz. 60 lat badań Instytutu Archeologii i Etnologii PAN w Kaliszu, [w: ] Wokót początków Kalisza. 60 lat stacji archeologicznej Instytutu Archeologii i Etnologii PAN w Kaliszu, red. D. Cygnot, A. Kędzierski, D. Wyczółkowski, WarszawaKalisz 2016, s. 89, 95. Pełne omówienie lokalizacji przęślików z łupku owruckiego w następującej pracy: M. Michalik, S.V. Pavlenko, M. Paszkowski, A.P. Tomaševskij, M. Wołoszyn, Wyroby, s. 57. 76 Najlepszym przykładem takiej nekropolii jest kujawska Bodzia, zob. K. Zamelska-Monczak, Wyroby z poroża i kamienia, [w:] Bodzia. Elitarny cmentarz z początków państwa polskiego, red. A. Buko, Warszawa 2016, s. 280.

77 Mapę zasięgu przęślików z łupku owruckiego można znaleźć w pracy następującej autorki: D. Dominiczak-Głowacka, Prześliki z wczesnośredniowiecznego grodziska w Grzybowie, $w$ województwie wielkopolskim nieopodal Wrześni, Studia Lednickie 9 (2008), s. 246 (ryc. 4). Wypada również dodać, że pojedyncze egzemplarze przęślików z łupku owruckiego odkrywano także na terenie Szwecji, zob. M. Wołoszyn, I. Florkiewicz, A. Jusupović, M. Michalik, M. Paszkowski, A. Kuligiewicz, M. Osiadacz, S. Pavlenko, A. Tomaševskij, Między skryptorium a laboratorium. Przęślik z Czermna (badania 1952 r.) $w$ świetle analiz archeologicznych, geologicznych i paleograficznych, [w:] Od Bachórza do Światowida ze Zbrucza. Tworzenie się słowiańskiej Europy w ujęciu źródłoznawczym. Księga jubileuszowa Profesora Michała Parczewskiego, red. B. Chudzińska, M. Wojenka, M. Wołoszyn, Kraków-Rzeszów 2016, s. 601. 
brać pod uwagę taką ewentualność, że przęśliki z łupku wołyńskiego stanowiły środek płatniczy ${ }^{79}$. Bez względu jednak na wyjaśnienie problemu funkcji tych przedmiotów wypada stwierdzić, że ten materiał zabytkowy trafiał licznie na omawiany obszar Wielkopolski i Kujaw, co świadczy o intensywnych kontaktach polsko-ruskich.

Mniej licznymi znaleziskami, które można uznać za pochodzące z terenów ruskich, są sprzączki lirowate (m.in. Brześć Kujawski, Brzoza, Kocanowo, Kruszwica, Międzyrzecz, Niepart, Ostrów Lednicki) ${ }^{80}$, pieczęcie (ruska pieczęć jest znana $\mathrm{z}$ Kalisza, aczkolwiek pochodzi ona dopiero z drugiej połowy XI w. $)^{81}$ czy wyroby szklane (np. pisanki - Brześć Kujawski, Kruszwica) ${ }^{82}$ oraz wreszcie niektóre dewocjonalia, które mogą mieć również genezę bizantyjską (enkolpion z Ostrowa Lednickiego) ${ }^{83}$. Szczególnie na tle tych wszystkich zabytków wyróżnia się odkryty na cmentarzysku w Bodzi pochówek mężczyzny z okuciem pasa z wygrawerowanym dwuzębem, gdzie jeden z zębów jest zakończony krzyżem, do którego znaleziono

79 S. Franklin, Writing, Society and Culture in Early Rus, c. 950-1300, Cambridge 2002, s. 79; S. Wadyl, Przęślik z quasi-inskrypcją cyrylicka z grodziska w Węgrach, gm. Sztum, Pomorania Antiqua 25 (2016), s. 271.

80 M. Wołoszyn, Bizantyjskie i ruskie, s. 8.

81 A. Jusupovic, P. Nowak, Bulla księcia ruskiego Izjasława Dymitra Jaroslawowicza, [w:] Wokół początków Kalisza. 60 lat stacji archeologicznej Instytutu Archeologii i Etnologii PAN w Kaliszu, red. D. Cygnot, A. Kędzierski, D. Wyczółkowski, Warszawa-Kalisz 2016, s. 24.

82 Na temat wzorców płynących z Rusi, a odnoszących się do idei wytwórczości szklarskiej, zob. E. Siemianowska, Wczesnośredniowieczne grzechotki i pisanki w strefie przebiegu szklaku lądowego z Rusi na Pomorze, [w:] Kultura materialna średniowiecza w Polsce. Materiaty ze studenckiej konferencji naukowej Toruń, 24-25 kwietnia 2008 roku, red. P. Kucypera, S. Wadyl, Toruń 2008, s. 70; M. Wołoszyn, Bizantyjski i łaciński model chrystianizacji $w$ świetle danych archeologicznych - uwagi dyskusyjne, [w: ] „In silvis, campis... et urbe” średniowieczny obrządek pogrzebowy na pograniczu polsko-ruskim, red. S. Cygan, M. Glinianowicz, P.N. Kotowicz, Rzeszów-Sanok 2011, s. 22-23; J. Sawicka, Czy w Kruszwicy wytapiano szkło? Z badań nad wytwórczością szklarską w Kruszwicy, [w: ] Od Popiela do Kazimierza Wielkiego. Księga Jubileuszowa dedykowana Wojciechowi Dzieduszyckiemu, red. M. Brzostowicz, T. Kasprowicz, M. Przybył, J. Wrzesiński, Poznań 2018, s. 112. Pisanki z Brześcia Kujawskiego i Kruszwicy zostały omówione w następujących tekstach: E. i Z. Kaszewscy, Wczesnośredniowieczne cmentarzysko w Brześciu Kujawskim, pow. Wtocławek, Materiały Starożytne i Wczesnośredniowieczne 1 (1971), s. 385-386; J. Kaczmarek, Wczesnośredniowieczne przedmioty szkliwione związane $z$ magia z Kruszwicy, [w:] Kraje słowiańskie w wiekach średnich. Profanum i sacrum, red. H. Kóčka-Krenz, W. Łosiński, Poznań 1998, s. 549-559.

83 J. Górecki, U źródet chrześcijaństwa w Polsce - relikwiarz drzewa Krzyża Świętego z Ostrowa Lednickiego, [w:] Stauroteka lednicka. Materiały, studia i analizy, red. A.M. Wyrwa, wyd. 2, Lednica 2015, s. 29-31. 
analogie na monetach Świętopełka I, księcia ruskiego, o którym już wspominaliśmy we wcześniejszych partiach opracowania ${ }^{84}$. Jak się okazuje, nie jest to jedyny tego rodzaju zabytek, z wielkopolskiego Giecza znamy bowiem okucie brązowe również $\mathrm{z}$ domniemanym znakiem Rurykowiczów ${ }^{85}$. Jeśli analogie te są trafne, to można by stwierdzić, że obecność ruska (przedmioty, ludzie, idee) była znacząco większa niż dotychczas przypuszczano, a dobrze ten problem ilustruje materiał archeologiczny.

\section{Podsumowanie}

Z powyższych rozważań rysuje się dość jasny, choć wciąż niekompletny obraz obecności ludzi, przedmiotów oraz idei ruskich (wpływów) we wczesnym władztwie Piastów. Już z materiału pisanego wynika, że kontakty polsko-ruskie były intensywne: koligacje rodzinne (Piastowie-Rurykowicze), konflikty czy wreszcie układy, informacje o tych wszystkich wydarzeniach znajdujemy na kartach źródeł pisanych. Obraz ten uzupełnia materiał toponomastyczny, który zdaje się potwierdzać obecność brańców ruskich na ziemiach władztwa Piastów, z którą już wcześniej spotkaliśmy się w źródłach pisanych. Należy przy tym jednak podkreślić, że nazewnictwo miejscowe w przypadku ludności ruskiej nie jest łatwym materiałem w interpretacji. Wreszcie dla omawianego przedziału czasowego, zamykającego się między panowaniem Mieszka I a końcem rządów Mieszka II, odnotowujemy również dość liczne źródła archeologiczne, które przynajmniej częściowo są związane z analizowanym obszarem oddziaływań. Wydaje się, że prezentowany w tym artykule materiał bardzo wyraźnie potwierdza intensywność kontaktów polsko-ruskich. Jednocześnie uważamy, że w przyszłości należałoby jeszcze raz przeanalizować materiał źródłowy dotyczący drużyny książęcej, albowiem niewykluczone, że w jej składzie znaczącą rolę ogrywali Rusini czy Waregowie, ale pochodzący właśnie z Rusi. Wszystkie te kwestie wymagają kolejnych badań i należy postulować, aby w przyszłości problematyka wpływów ruskich we władztwie Piastów znalazła odbicie w nowym, odrębnym opracowaniu książkowym.

84 K. Kollinger, Polityka wschodnia, s. 373. Por. A. Buko, Cmentarzysko w Bodzi w świetle wyników badań interdyscyplinarnych, [w:] Bodzia. Elitarnym cmentarz z początków państwa polskiego, red. A. Buko, Warszawa 2016, s. 503. Dużo większą ostrożność w tym względzie zachowywał W. Duczko, Status i magia. Ozdoby elit z Bodzi, [w: ] Bodzia. Elitarnym cmentarz, s. $146-148$.

85 T. Krysztofiak, Okucie ze znakiem Ruryka znalezione w Gieczu, Archeologia Polski 58 (2013), z. 1-2, s. 115-124. Warto dodać, że autorka przedstawiła również inne tego typu znaki występujące na zabytkach z różnych części władztwa Piastów. 
Dr Marcin Danielewski

Wydział Archeologii

Uniwersytet im. Adama Mickiewicza w Poznaniu

Uniwersytetu Poznańskiego 7

61-614 Poznań

e-mail:m_danielewski@tlen.pl

Nadesłany: 1.07.2019

Nadesłany po poprawkach recenzyjnych: 5.11.2019

Zaakceptowany: 10.11.2019

\section{Summary}

This paper attempts to get an insight into the issue of the Ruthenian influence in the Piast realm using an interdisciplinary approach. Beginning with the reign of Mieszko I and closing with the end of Mieszko II' rule, this period abounded in Polish-Ruthenian contacts that entailed the exchange of people, ideas and objects. The contacts are very well illustrated by written sources and in archaeological record. To some extent, this image is further complemented by toponomastic material, which probably largely reflects the remains of the captive settlement of the Ruthenian population in the area occupied by the Piast domain. The discussed problem seems to be particularly important from the point of view of further research. The paper encourages the studies on the Polish-Ruthenian contacts in the early Middle Ages to be continued. 